Grzegorz Sztabiński

Uniwersytet Łódzki

\title{
Przewodnik czy uczestnik: jak współcześni estetycy widzą rolę pośrednika w relacjach sztuka - odbiorca
}

Rozważając dwadzieścia lat temu relacje sztuki i estetyki Wolfgang Welsch, ujmował je jako „usługi z dziedziny public relations”. Podkreślał, że rezultaty twórczości artystycznej nie znajdują dziś, jak działo się dawniej, oczywistego uznania kulturowego. Kontakt ze sztuką przestał być uważany za coś wskazanego i wiążącego. W tej sytuacji niezbędne stało się wsparcie ze strony filozofii. „Estetyka - pisał Welsch - stała się kulturową agencją reklamową, propagującą produkt o nazwie "sztuka»"2. Wyjaśniając powody tej sytuacji niemiecki estetyk wskazywał na postępujący od kilku stuleci proces autonomizacji, który doprowadził do utraty więzi między rezultatami działań artystycznych a powszechną świadomością. Estetyka miała na nowo wykazać, że sztuka jest znacząca, ważna dla całokształtu kultury i życia jednostek ludzkich. „Miała na powrót uczynić sztukę przedmiotem powszechnego zainteresowania"3.

W owym procesie estetycy przypisywali sobie rolę tych, którzy formułują teoretyczne uzasadnienia. Natomiast działania praktyczne przekazywali zwykle innym. Rola bezpośredniego wykonawcy w relacjach sztuka - odbiorca z punktu widzenia estetyki wydawała się więc stosunkowo jasna. Pośrednik, którym mógł być zarówno krytyk artystyczny jak i pedagog, miał przede wszystkim budzić zainteresowanie sztuką, ale jednocześnie dążyć do tego, żeby jej odbiór był właściwy. W związku z tym istotna była selekcja dzieł, na których należy koncentrować uwagę odbiorców. Dokonywano więc ocen i kształtowano kanony utworów najistotniejszych z punktu widzenia tradycji kulturowej. Równocześnie jednak, korzystając ze wskazań estetyków, ustalano zasady dotyczące właściwego sposobu korzystania z nich. Ten zakres

\footnotetext{
${ }^{1} \mathrm{~W}$. Welsch, Filozofia i sztuka - wzajemne relacje. Tematyka i cel, [w:] idem, Estetyka poza estetyką. O nowa postać estetyki, przeł. K. Guczalska, Kraków 2005, s. 3.

${ }^{2}$ Ibidem.

${ }^{3}$ Ibidem, s. 6.
} 
działań zwłaszcza od połowy XIX wieku uznany został za istotny. „W ostatnich stu latach - pisał około 1975 roku Władysław Tatarkiewicz - większość bodaj publikacji o pięknie i sztuce miała charakter psychologiczny, tematem ich było to przeżycie wobec piękna i sztuki, które się nazywa przeżyciem (lub doznaniem, lub doświadczeniem) estetycznym. Dochodzono, jakie ma właściwości, jaki przebieg, jakie składniki, jakiej wymaga postawy psychicznej”4 Nie oznacza to, że wcześniej problemem tym nie interesowano się. Nazwa „przeżycie estetyczne” pojawiła się wprawdzie w XVIII wieku, jednak już w poprzednich stuleciach zwracano uwagę, że kontakt z pięknymi przedmiotami wywołuje szczególny stan psychiczny. Od starożytności pisano, że człowiek staje się wówczas podobny do zaczarowanego przez syreny, jakby bezwolny. Sądzono jednak, że osiągnięcie go nie jest związane ze szczególnym nastawieniem zmysłowo-psychicznym, wystarczy zwykłe widzenie lub słuchanie. W wieku XVIII powstała idea, że przeżycie estetyczne wymaga swoistej zdolności. Określono ją jako smak (taste, goût) i prowadzono spory dotyczące tego, czy przysługuje ludziom w równym stopniu, czy też dany jest tylko niektórym osobom. Inny rodzaj sporów obejmował kwestie relacji między poczuciem piękna a poczuciem moralności. Niekiedy je łączono, innym razem rozdzielano, podkreślając, że „zmysł piękna” nie łączy się $\mathrm{z}$ wiedzą racjonalną ${ }^{5}$. W dalszych wiekach także nie stworzono jednolitej koncepcji przeżyć estetycznych. Obok teorii akcentujących rolę czynników zmysłowych wich powstaniu, rozwijane były poglądy intelektualistyczne, których przedstawiciele zwracali uwagę na to, że przeżycie estetyczne zwłaszcza w przypadku dzieł sztuki powinno być poprzedzone szeregiem czynności umysłowych pozwalających właściwie ująć percypowany obiekt.

W XX wieku estetykiem, który poświęcił wiele uwagi roli pośredników między sztuką a odbiorcami był Monroe C. Beardsley. Koncentrował się on przede wszystkim na właściwym określeniu miejsca i roli krytyki artystycznej. Zwracał uwagę na wzajemną zależność między działalnością estetyka i krytyka sztuki. Ten drugi, bezpośrednio odnosząc się do konkretnych dzieł, może wskazywać istotne problemy teoretyczne, a także ustawicznie testować i częściowo weryfikować lub falsyfikować koncepcje estetyczne. Natomiast estetyk poprzez swe rozważania powinien sprzyjać doskonaleniu krytyki artystycznej poprzez eliminowanie tych praktyk, które są nie-

\footnotetext{
${ }^{4}$ W. Tatarkiewicz, Dzieje sześciu pojęć, Warszawa 1975, s. 361.

${ }^{5}$ Krótki przegląd historii sporów związanych z pojmowaniem przeżycia estetycznego znaleźć można w cytowanej wyżej książce Tatarkiewicza.
} 
adekwatne do natury sztuki, bądź oparte na błędnych założeniach ${ }^{6}$. Ma on więc prawo i obowiązek zwracania uwagi na to, co powinno stanowić przedmiot zainteresowania krytyka i jakie cele powinien on przyjmować w swej działalności. Zdaniem Beardsleya zadaniem krytyki artystycznej jest odkrywanie w dziełach sztuki tych własności, które decydują o ich wartości estetycznej. Brał on pod uwagę, że mogą cechować je również inne wartości (np. poznawcze lub moralne), nie traktował ich jednak jako zasadniczej podstawy wartościowania utworów artystycznych. Celem krytyka sztuki jest więc zmierzanie do określenia tego, co zasadnie wzbudza podziw odbiorców i stanowi podstawę właściwej oceny. Estetyk może pomóc mu we właściwym ukierunkowaniu tych czynności.

Amerykański estetyk zwracał uwagę, że doświadczenie ma charakter estetyczny, gdy jest ukierunkowane na przedmiot i skoncentrowane na obiektywnych własnościach tego, co percypowane lub wyobrażone ${ }^{7}$. Doświadczenie takie przynosi nam poczucie wolności polegające na wyzwoleniu od trosk dotyczących przyszłości lub przeszłości, wyzwala „izolację afektów”, wywołuje poczucie „aktywnego odkrycia”, wprowadza rodzaj ożywienia w ujmowaniu związków między wrażeniami zmysłowymi i znaczeniami oraz daje „poczucie całości” poprzez zharmonizowanie impulsów i uczuć8. Krytycy sztuki powinni, biorąc pod uwagę te czynniki, formułować oceny dzieł sztuki uwzględniające rodzaj i stopień osiągniętej w nich wartości.

Koncepcja estetyczna Beardsleya ma charakter uniwersalistyczny. Autor jej zakładał, że właściwe doświadczenie estetyczne przebiegać powinno podobnie we wszystkich przypadkach i prowadzić do zbliżonych celów niezależnie od tego, z jakim dziełem sztuki mamy do czynienia. Nie wprowadzał on pod tym względem istotnych rozróżnień związanych z poszczególnymi epokami czy stylami artystycznymi, a nawet nie uwzględniał odmienności dzieł pochodzących z innych kręgów geograficznych i kulturowych. Sądził, że kontakt ze sztuką powinien być odnoszony do kwestii dotyczących tego, co w życiu ludzkim przynosi szczęście, daje poczucie doświadczenia

\footnotetext{
${ }^{6}$ M. C. Beardsley, The Aesthetic Point of View. Selected Essays, eds. M. J. Wreen, M. D. Callen, Ithaca 1982, s. 317-318. W Polsce o Beardsleyowskiej koncepcji relacji estetyki i krytyki artystycznej pisał Bohdan Dziemidok w książce Główne kontrowersje estetyki wspótczesnej (Warszawa 2002, s. 95-97), z którego uwag tu częściowo korzystam.

${ }^{7}$ Biorąc to pod uwagę, Dziemidok zalicza poglądy Beardsleya do „perceptualizmu estetycznego”.

${ }^{8}$ M. C. Beardsley, Aesthetics: Problems in Philosophy of Criticism, New York 1958, s. 573-576. Dziemidok analizuje tę wersję poglądów Beardsleya, porównując ją z jego wcześniejszymi zapatrywaniami i wskazując na związki z koncepcją Johna Deweya (B. Dziemidok, Główne kontrowersje..., s. $88-93)$.
} 
sensu egzystencji, pomyślności, i że nie trzeba tych zagadnień zanadto różnicować. Pomimo różnorodności rozstrzygnięć, jakie w związku z tymi zagadnieniami mogą być przyjmowane w filozofii czy pedagogice, dobrze jest doznawać bezpośredniego poczucia wewnętrznej integracji i złożonej harmonii z postrzeganymi przedmiotami, a stany takie osiągamy dzięki doświadczeniom estetycznym ${ }^{9}$. Nie wszyscy estetycy podzielali jednak ten punkt widzenia. Według wielu z nich, właśnie uwzględnienie różnorodności koncepcji sztuki pojawiających się w różnych okresach historycznych, a także odmienności tradycji kulturowych, z których się wywodzą, pozwala wzbogacić zakres przeżyć estetycznych i uwzględnić ich zróżnicowany charakter. Dlatego akcentowali nie tyle to, co wspólne w doświadczeniach związanych z odbiorem sztuki, lecz sugerowali uwzględnianie specyficzności, odmienności możliwych reakcji.

Przykładem takiej koncepcji mogą być poglądy Mieczysława Wallisa. Przyjmując pluralistyczne podejście do sztuki, a także doświadczeń estetycznych, podkreślał on potrzebę rozróżnienia nie tylko dzieł "pięknych” i „brzydkich”, „dobrych i złych”, ale również „swojskich” i „obcych”. Kwestionował w związku z tym pogląd, że ,jakieś wybitne dzieło sztuki powinno przemawiać do każdego, posiadającego pewne minimum wrażliwości estetycznej, bez względu na to, z jakiej epoki lub z jakiego kraju ono pochodzi”, a ponadto, że „każdy człowiek, posiadający pewne minimum wrażliwości estetycznej, postawiony wobec jakiegoś wybitnego dzieła sztuki, powinien zareagować na to dzieło we właściwy sposób" ${ }^{10}$. Twierdził, że w taki bezpośredni, niewymagający specjalnego przygotowania sposób przemawia tylko sztuka „swojska”, do recepcji której odbiorca był przygotowywany nieświadomie od najmłodszych lat. Natomiast dzieła „obce” (pochodzące z wcześniejszych epok lub innych kręgów kulturowych) wymagają, dla wywołania właściwego przeżycia estetycznego, znacznego wysiłku intelektualnego, nierzadko specjalnych studiów i długotrwałego „treningu”. Aby ich doświadczyć, odbiorca musi się „zapoznać najdokładniej z ich założeniami i ideałami artystycznymi i długo ćwiczyć się i wprawiać w ich właściwym spostrzeganiu i interpretowaniu"11. Służyć ma temu rozumienie, pojmował je Wallis jako czynność intelektualną, dzięki której widziane lub słyszane dzieło staje się „swojskie” (w większym lub mniejszym stopniu) i w związku z tym staje się przedmiotem przeżycia estetycznego, „jakie chciał wywołać

\footnotetext{
${ }^{9}$ M. C. Beardsley, The Aesthetic Point of View..., s. 370.

${ }^{10}$ M. Wallis, Przeżycie i wartość, Kraków 1968, s. 65.

${ }^{11}$ Ibidem, s. 66.
} 
w nas twórca tego dzieła"12. Pomocy w wykonaniu tej czynności udzielać mieli pośrednicy: krytycy artystyczni i pedagodzy sztuki.

Koncepcje tego typu jak omówiona krótko teoria Wallisa mają charakter intelektualistyczny i intencjonalny. Intelektualizm ów nie polega na tym, że kwestionuje się w obcowaniu ze sztuką rolę emocji. Przeżycie estetyczne jednak musi być przygotowane i odpowiednio ukierunkowane. Czynności intelektualne, jak podkreślał polski autor, „są warunkiem niezbędnym "właściwego» przeżycia estetycznego"13, gdyż pozwalają ująć dzieło sztuki we właściwy sposób, czyli zgodnie z intencjami twórcy. Tylko taki zaś sposób ujęcia zapewnia wystąpienie właściwego rodzaju doznań i stwarza możliwość sformułowania na ich podstawie „ważnej” oceny estetycznej. Inne uczucia, jakie mogą pojawiać się podczas kontaktu z dziełem, jeśli nawet są silne i bogate, prowadzą do ocen „nieważnych”, gdyż nie odpowiadają temu, co stanowi intencjonalną istotę utworu. Rola pośrednika związana ma być więc z odpowiednim przygotowaniem recepcji. Dzięki dostarczeniu odbiorcy odpowiedniej wiedzy może zajść proces zrozumienia utworu, uczynienia go swojskim na płaszczyźnie intelektualnej. Natomiast siła doznania emocjonalnego pozostaje sprawą indywidualną, uzależnioną w znacznym stopniu od czynników osobistych.

W teoriach estetycznych, w których akcentuje się uniwersalne oddziaływanie sztuki na odbiorców, rola czynności intelektualnych w czasie odbioru nie jest tak silnie podkreślana. Większe znaczenie przypisane zostaje czynnikom percepcyjnym (wzrokowym lub słuchowym), które ludzi łączą ponad różnicami kulturowymi, i takim stanom emocjonalnym, które są z nimi związane (odczucie koherencji, pełni, różnorodności i jedności zarazem). Nie oznacza to jednak, że rola krytyka lub pedagoga sztuki zostaje wówczas ograniczona. Działalność jego ukierunkowuje się wówczas inaczej - na wskazywanie ludziom doniosłości estetycznych doznań i określanie ich miejsca i roli w całokształcie życia.

Na przykładzie koncepcji Beardsleya i Wallisa zwróciłem tu uwagę na dwie drogi podkreślania przez estetyków wagi dzieł artystycznych, wskazywania ich jako czegoś istotnego i wiążącego. Jeśli, jak sugerował cytowany na początku tego tekstu Welsch, estetyka stała się w ciągu ostatnich wieków kulturową agencją reklamującą produkt o nazwie „sztuka”, to do działań tych, na co zwracałem uwagę, w znacznym stopniu zaangażowani

\footnotetext{
${ }^{12}$ Ibidem, s. 81.

${ }^{13}$ Ibidem, s. 76.
} 
zostali pośrednicy - krytycy sztuki i pedagodzy. Twórcy teorii estetycznych przypisali sobie funkcję prawodawców ustanawiających bardziej lub mniej jawnie normy i przepisy. Dla pośredników przewidywali natomiast rolę przewodników kierujących odbiorcami. Pełnienie tych funkcji utrudniał jednak w znacznym stopniu rozwój twórczości awangardowej. Zwykle nie wpisywała się ona łatwo w ramy ogólnych koncepcji estetycznych. Dlatego uwzględnienie jej w praktyce krytycznej i pedagogicznej traktowane było często jako rodzaj wyzwania.

Oczywiście trudności związane z wzięciem pod uwagę nowoczesnych dokonań twórczych miały odmienny charakter w zależności od rodzaju koncepcji estetycznej. Na przykład z punktu widzenia założeń perceptualizmu szczególnie kłopotliwa była działalność Marcela Duchampa, a w szczególności jego ready-mades. W przypadku wyboru gotowego przedmiotu wyprodukowanego fabrycznie (np. pisuaru lub suszarki do butelek) i nadania mu rangi dzieła sztuki czynnik wizualny w czasie odbioru okazywał się mało istotny. Percepcja jakości zmysłowych traciła pierwszoplanową rolę. Punkt ciężkości w czasie odbioru przenosił się na operacje intelektualne - zwłaszcza pytanie: dlaczego to jest sztuka? Beardsley akcentował w związku z tym, że ready-mades Duchampa „nie zostały wytworzone $\mathrm{z}$ intencją wzbudzania przeżycia estetycznego, lecz np. z intencją szokowania" ${ }^{\prime 4}$. Nie spełniają więc warunku koniecznego dzieła sztuki, jakim jest związek z estetycznością. Natomiast w przypadku teorii, w których podkreśla się rolę czynnika intelektualnego w odbiorze sztuki, trudność ta wydawała się mniej groźna. Można było przecież zakładać, że nowe propozycje artystyczne wymagają od odbiorcy tylko odpowiednio przeprowadzonych czynności myślowych, aby mógł on osiągnąć zrozumienie dążeń artystycznych i dzieło „obce” przemienić w „swojskie”. Kłopot polegał jednak na tym, że szczególnie radykalne dokonania awangardowe i neoawangardowe przekraczały paradygmat estetyczny w tym sensie, że ich celem nie było wywoływanie przeżyć estetycznych, nawet „ostrych”, jak je określał Wallis (a więc oszołomienia, zdumienia, przerażenia, lęku, zgrozy ${ }^{15}$ ), lecz prowokowanie odbiorcy do refleksji. Niektórzy krytycy i teoretycy sztuki wyprowadzali z tego radykalne wnioski. Jeśli sensem kontaktów ze sztuką jest pobudzenie zainteresowania widza i skłonienie go do myślenia, a nie przeżywania, to wydawanie sądów estetycznych staje się nieuzasadnione. Pisał o tym Richard Kostelanetz:

\footnotetext{
${ }^{14}$ B. Dziemidok, Główne kontrowersje..., s. 82.

${ }^{15}$ M. Wallis, Przeżycie i wartość..., s. 189.
} 
„Dlaczego marnować wasz czas i mój, próbując wydawać sądy wartościujące? [...] Sądy wartościujące są destrukcyjne dla naszych własnych istotnych spraw, jakimi są ciekawość i zdobywanie świadomości czegos’" ${ }^{\prime 6}$.

Estetyczne wypowiedzi oceniające pełniły bardzo istotną funkcję w działalności pośredników sztuki, którzy odgrywali role przewodników. Autorytet, jakim się cieszyli, uprawniał ich do zwracania uwagi na to, co w sztuce uważali za istotne. Za pomocą sądów wartościujących mogli więc stymulować odbiorców do zainteresowania się określonymi dziełami sztuki, a także skupiać ich wokół określonych zjawisk artystycznych i sugerować, w jaki sposób powinny być one odbierane. Tak pojęta funkcja integracyjna odgrywała zaś istotną rolę w estetycznym pośrednictwie. Natomiast sugerowana przez Kostelanetza rezygnacja $\mathrm{z}$ formułowania ocen estetycznych motywowana była między innymi tym, żeby każdemu odbiorcy pozostawić możliwość odnajdywania w sztuce tego, co dla niego istotne, indywidualnego zmierzenia się z dziełem. Zakładało to dojrzałość widza, uwzględniało jego wolność i stwarzało każdemu podstawy do aktywnego, twórczego odniesienia się do sztuki.

Rola aktywności odbiorczej i działań o charakterze partycypacyjnym była brana pod uwagę $\mathrm{w}$ wielu koncepcjach estetycznych formułowanych w latach sześćdziesiątych i siedemdziesiątych XX wieku. Autorzy tych teorii odwoływali się często do neoawangardowych tendencji artystycznych, jakie się wówczas rodziły. W sztuce kinetycznej, happeningach, sztuce environment i performance, a także w wielu eksperymentach muzycznych i literackich przełamywano podział na działalność twórczą prowadzącą do wytworzenia dzieła sztuki, i receptywny, bierny odbiór, który, jak dawniej podkreślano, powinien być adekwatny wobec założeń artysty. Zmierzano do zaktywizowania widza, uczynienia go aktywnym współuczestnikiem sytuacji estetycznej.

Jedną z najważniejszych koncepcji tego typu jest teoria „dzieła otwartego" sformułowana przez Umberta Eco. Autor jej zakładał, że cechy odbioru występujące $\mathrm{w}$ związku z twórczością neoawangardową nie powinny być traktowane jako specyficzne, odróżniające ją od sztuki wcześniejszej. Przeciwnie, sądził, iż są one tylko szczególnie dobitnym zaakcentowaniem tego, co występowało także w sztuce dawnej. Eco pisał, że

\footnotetext{
${ }^{16}$ R. Kostelanetz, We Don't Know Any Longer Who I Was (Interview with John Cage), ,The New York Times", March 17, 1968, [cyt. za:] U. Meyer, Conceptual Art, New York 1972, s. VIII [tłum. cytatów w całej pracy moje - G. Sz.].
} 
w istocie każde dzieło sztuki, nawet jeśli powstało przy jawnym lub ukrytym zastosowaniu poetyki konieczności, jest $\mathrm{z}$ istoty swej otwarte na potencjalnie nieskończoną serię możliwych interpretacji, z których każda pozwala dziełu odżyć na nowo, wedle jakiejś perspektywy, jakiegoś gustu czy indywidualnego wy konania ${ }^{17}$.

Każde dzieło sztuki, także pochodzące z przeszłości, nie musi być odczytywane tylko przy uwzględnieniu tych założeń, które właściwe były dla okresu jego powstania. Nie ma też uniwersalnego sposobu odbioru. Dzieła w istocie były i mogą być obecnie odczytywane na różne sposoby, w zależności od aktualnych problemów, przed jakimi stają osoby zainteresowane nimi. Wszystkie koncepcje właściwego odbioru sztuki tworzone przez estetyków były tylko próbą uzasadnienia ich indywidualnego sposobu recepcji, któremu starano się nadać wartość normy powszechnie uznawanej. Odwoływano się też jawnie lub w sposób ukryty do różnych autorytetów (np. kościelnych, państwowych lub akademickich - w zależności od okresu historycznego), aby tym sposobom czytania nadać odpowiednią rangę. Pośrednicy sztuki byli wykonawcami w procesie wdrażania zaleceń estetycznych. Tymczasem, jak pisał Eco, „każda lektura, każde kontemplowanie, każde przeżycie estetyczne dzieła sztuki stanowi pewien rodzaj indywidualnego wykonania"18. Niepotrzebni są w tym procesie przewodnicy, natomiast wszyscy stajemy się współuczestnikami.

Koncepcja współuczestnictwa może jednak być pojmowana dwojako. Zawierać się w niej może dążenie do zbiorowego rozwoju, ale rysuje się też obraz stagnacji, ograniczenia do powtarzania raz przyjętych wzorów. Eco uważał, że rzeczywistość dynamicznie zmienia się i w związku z tym głównym problemem jest wypracowanie sposobów reagowania w nowych sytuacjach. Pomóc może w tym kontakt ze sztuką uwzględniający indywidualną inwencję interpretacyjną. Jeśli pewne ludy określamy jako pierwotne, twierdził włoski estetyk, to nie dlatego, że model kultury, który wypracowały, był barbarzyński i nieużyteczny, gdyż okazywał się on użyteczny w sytuacji, w któej go tworzono, ale dlatego, że nie był on podatny na ewolucję. W związku z tym przedstawiciele owej kultury, przyjmując biernie ów model,

nie potrafili potęgować jego początkowych możliwości i ograniczali się do akceptowania pierwotnych doświadczeń jako pustych formuł, elementów rytu-

\footnotetext{
${ }^{17}$ U. Eco, Dzieło otwarte. Forma i nieokreśloność w poetykach wspótczesnych, tłum. J. Gałuszka, L. Eustachiewicz, A. Kreisberg, M. Olesiuk, Warszawa 1972, s. 54.

${ }^{18}$ Ibidem, s. 25.
} 
ału, nietykalnych tabu. Niewiele mamy powodów, by mówić o przewadze modelu współczesnej kultury Zachodu nad innymi modelami. Jedną z racji przemawiających na jego korzyść jest wszakże plastyczność, umiejętność reagowania na rzucane przez okoliczności wyzwania, poprzez wypracowywanie wciąż nowych modułów adaptacyjnych i nowych korektur nabytych doświadczeńn ${ }^{19}$.

Kontakt ze sztuką można więc uznać za swoistą lekcję otwartości i inwencji, z której wnioski i nabyte dyspozycje mogą następnie być przenoszone do różnych sytuacji zachodzących w codziennej praktyce.

Czy jednak ta umiejętność reagowania na nowe, odmienne sytuacje pojawia się samorzutnie? Czy tendencja do biernego akceptowania pewnych wzorców postępowania, traktowanych jako gotowe formuły, nie występuje również u osób żyjących we współczesnej kulturze Zachodu? Niektórzy estetycy zadawali w związku z tym pytanie: czy jednak pośrednicy działający na nowych zasadach nie są konieczni? Poszukiwali też rozwiązania problemu, kto mógłby obecnie taką rolę odgrywać. W latach sześćdziesiątych i siedemdziesiątych XX wieku wskazywano zwykle na artystów. Nie traktowano ich już wówczas jako wytwórców dzieł, których właściwy odbiór wymaga współpracy krytyka artystycznego, a jako twórców nowych definicji sztuki, a także szerszych koncepcji wpływających na stosunek człowieka do rzeczywistości i sposób pojmowania przez niego celów życiowych. Artyści stawali się więc pedagogami w odniesieniu do całego społeczeństwa. Zadaniem ich było już nie tworzenie przedmiotów przeznaczonych do biernej kontemplacji, a apelowanie do odbiorcy o włączenie się w proces twórczy, stanie się współtwórcą. Wypracowane w ten sposób dyspozycje kreatywne odbiorców miały być następnie przenoszone do praktyki życiowej w różnych wykonywanych przez nich zawodach. Zauważał to Frank Popper, pisząc w 1975 roku: „W efekcie, współczesny artysta przekazuje już część swej odpowiedzialności widzowi. W związku z tym chce stać się pośrednikiem i programistą [...]”20. W przeciwieństwie do „klasycznego artysty” nie koncentruje się na aspekcie przedmiotowym dzieł sztuki, a pragnie partycypacji odbiorcy i jego kreatywności. Chce przezwyciężyć konsumpcyjne podejście do sztuki, kształtując nowe formy zachowań lub propozycje modyfikacji materialnego i kulturalnego otoczenia.

Popper uważa, że „fałszywe” pojmowanie twórczości związane jest $\mathrm{z}$ „pomyleniem porywczej [hasty] formy działania, opartej na przyjętych ideach i przestarzałych pojęciach (spontaniczna praktyka nieróżniąca się

\footnotetext{
${ }^{19}$ Ibidem, s. $150-151$.

${ }^{20}$ F. Popper, Art - Action and Participation, London 1975, s. 278.
} 
zasadniczo od sztuki patologicznej albo kiczu) z oryginalną i rozważną poetyką"21. Pomyłka taka występowała często u estetyków i krytyków sztuki, ale, co gorsze, upowszechniana była przez pedagogów. Dlatego wszyscy oni traktowali dzieła sztuki jako dziwaczne spektakle dostarczające niezwykłych wrażeń, przynoszące rozrywkę zachowującym bezpieczny dystans, pogrążonym w bierności odbiorcom. Głosząc koncepcję nowej estetyki, związanej z dokonaniami neoawangardowymi, Popper pisał, że „publiczność musi zaakceptować ciągłą wymianę pomiędzy twórczością i refleksją, teorią i praktyką"22 i zdać sobie sprawę z tego, że w procesie twórczym między artystą a odbiorcami zachodzi dopełnianie się. Prowadzi to do nowej definicji estetyki, w której wrażenia zmysłowe i refleksja współwystępują. Nowy estetyk sytuuje się nie ponad badanymi zjawiskami, a "plasuje się wewnątrz procesu twórczego, na tym samym poziomie co artysta i uczestnicząca publicznośćc ${ }^{3}$. „Publiczna twórczość” powinna stać się punktem wyjścia autoanalizy estetycznych potrzeb i aspiracji. Nowa estetyka powinna więc być połączona z nowym demokratycznym pojmowaniem sztuki. To, co indywidualne zajmie wówczas miejsce wewnątrz społecznych wzorów, ale nie na zasadzie przystosowania, a dialektycznych odniesień między tym, co pozytywne i negatywne. Upodmiotowiony odbiorca będzie uczestniczył w podejmowaniu decyzji. Władza dotycząca estetycznych decyzji spocznie w rękach wszystkich. Każdy będzie współdecydował o sztuce. Popper twierdził, że ta „władza identyfikowania własnych estetycznych potrzeb, aspiracji i przeznaczenia jest jedyną drogą prowadzącą do przeciwnej kiczowi, antyakademickiej i antyelitarystycznej przyszłości artystycznej"24.

Hasło nowego, demokratycznego pojmowania sztuki, o którym pisał Popper, pojawiało się w latach sześćdziesiątych i siedemdziesiątych XX wieku w programach wielu nurtów neoawangardy. Zakładano w nim, że każdy człowiek jest twórczy, każdy może, jak artysta, działać w sposób pełen inwencji na swym stanowisku pracy. Kontakt ze sztuką stać się miał wobec tego wyzwoleniem ogólnych zdolności twórczego działania ${ }^{25}$. W procesie

\footnotetext{
${ }^{21}$ Ibidem, s. 279.

${ }^{22}$ Ibidem, s. 280.

${ }^{23}$ Ibidem.

${ }^{24}$ Ibidem.
}

${ }^{25}$ Zwracał na to uwagę Joseph Beuys, podkreślając, że „państwo nie przypisuje już większej wartości artystycznemu czy estetycznemu wychowaniu człowieka, ale przypisuje ją reprodukcji inteligencji technicznej w imię utrzymania systemu". Natomiast niemiecki artysta opowiadał się za „takim wychowaniem artystycznym, które uzewnętrznia się nie tylko w czasie godzin malowania czy rysunku, ale za gruntownym wychowaniem estetycznym przenikającym wszystkie przedmioty. Można mianowicie jak najbardziej artystycznie poczynać sobie w matematyce, matematyka bowiem 
tym artyści odgrywać mogli rolę inicjatorów, ale zakres i przebieg postępowania uzależniany był od poszczególnych jednostek ludzkich. Tym, co miało je łączyć, był wspólny cel - ukształtowanie nowego człowieka, wolnego i kreatywnego, znajdującego szczęście w działaniu indywidualnym, które jednocześnie przyczynia się do dobra wspólnego ${ }^{26}$.

Demokratyzacja sztuki jest też ważnym hasłem w czasach obecnych. Pojmuje się ją jednak inaczej. Przede wszystkim hasło to pozbawione zostało elementów perspektywicznych i utopijnych. Współczesna demokracja estetyczna rozumiana jest jako stworzenie równych szans dla wszystkich. Dotyczy to zarówno dostępu do sztuki, jak i sposobów korzystania z niej. Sztuka stała się więc teraz wszechobecna. Można spotkać ją na wielkich imprezach, takich jak międzynarodowe biennale lub triennale, których liczba na całym świecie gwałtownie rośnie, w muzeach lokalizowanych chętnie w centrach handlowych, aby odbiorca nie musiał trudzić się, jeśli zechce je odwiedzić, a także w galeriach znajdujących się w różnych częściach miast, tak by ułatwić do nich dostęp. Praktycznie więc sztuki nie da się uniknąć. Jednocześnie zaś nie można jej ogarnąć. Nie da się obejrzeć wszystkich choćby najbardziej reklamowanych wystaw, przeczytać nagrodzonych na różnych konkursach książek, obejrzeć filmów, które uzyskały laury na jakichś festiwalach. Ta niemożność dotyczy nie tylko zwykłych odbiorców, ale również krytyków sztuki, których sugestie stają się w związku z tym wyrywkowe i przypadkowe. Zanika $\mathrm{z}$ tego powodu nie tylko tradycyjny model odbioru dzieł artystycznych oparty na indywidualnym, kontemplacyjnym skupieniu (gdyż nowe miejsca prezentacji sztuki nie stwarzają okazji do takiej samotnej koncentracji), ale również ten polegający na neoawangardowej partycypacji opartej na celowym ukierunkowaniu postępowania. Współczesne kontakty ze sztuką odbywają się w przestrzeni społecznej, w relacji z innymi, w sporze dyskursów, w natłoku wielu bodźców, od których nie można izolować się i których nie da się nawet hierarchicznie uporządkować.

Współczesna forma uczestnictwa w życiu artystycznym prowadzi też do zmiany roli pośredników. Nie pełnią oni już funkcji przewodników, gdyż

operuje formami” (J. Beuys, Każdy artystą, przeł. K. Krzemień, [w:] Zmierzch estetyki - rzekomy czy autentyczny?, wybrał i wstępem opatrzył S. Morawski, t. II, Warszawa 1987, s. 269).

${ }^{26}$ Występującą w poglądach neoawangardowych koncepcję bezkonfliktowego, pozbawionego przymusu połączenia wolnych działań indywidualnych z tym, co ważne z punktu widzenia zbiorowego omawiam szerzej w książce Inne idee awangardy: wspólnota, wolność, autorytet (Warszawa 2011, s. 85-106). 
demokratyzacja sztuki powoduje, że ich poglądy mogą być wzięte pod uwagę przez odbiorców, ale mogą też zostać w każdej chwili odrzucone. Nastąpił zanik autorytetów w sztuce. W propozycji „nowej estetyki” Poppera, o której pisałem wyżej, zanikał autorytet formalny, deontyczny, związany $\mathrm{z}$ umiejscowieniem $\mathrm{w}$ porządku instytucjonalnym ( $\mathrm{z}$ jakim mamy do czynienia w przypadku dowódcy wojskowego lub nauczyciela w szkole), natomiast liczyć się miał autorytet epistemiczny - tego, o kim sądzi się, że wie lepiej, a więc należy mu zaufać ${ }^{27}$. Obecnie zauważalny jest $\mathrm{w}$ odniesieniu do sztuki zmierzch obu odmian autorytetu. Nie posiadają go artyści, którzy zabiegają głównie, a być może wyłącznie, o wysokie notowania w ramach różnych rankingów, a te sporządzane są często według cen uzyskiwanych za sprzedawane prace. Nie mają go też krytycy sztuki, gdyż z ich werdyktami odbiorcy liczą się rzadko przy podejmowaniu estetycznych decyzji. Dobrym przykładem tego stają się filmy bardzo źle oceniane przez krytykę, które mimo to są masowo oglądane i odnoszą wielki sukces finansowy. W tej sytuacji krytycy artystyczni poszukują nowych form działalności. W przypadku sztuk plastycznych polega to często na podkreśleniu roli działalności kuratorskiej. Krytyk przestaje być pośrednikiem przybliżającym odbiorcom konkretne dzieła, a zaczyna tworzyć według własnej koncepcji dyskursy sztuki. W ramach tak organizowanych wystaw prezentowane prace stają się tylko materiałem do stworzenia własnej wypowiedzi kuratora, co wywołuje często protesty artystów ${ }^{28}$.

Czy współcześni odbiorcy czują się zagubieni w związku z tą sytuacją? Można odnieść wrażenie, że raczej ochoczo na nią przystają. Nowa demokracja estetyczna uwalnia ich od obaw, że być może dzieła sztuki niewłaściwie percypują lub że ich nie rozumieją. Jeśli chcą, mogą skorzystać z uwag krytyka czy pedagoga sztuki. Nie jest to jednak konieczne, a uzyskane opinie nie muszą być brane pod uwagę. Podobnie jak w turystyce, przewodnik bywa przydatny, ale można też, zwiedzając, zrezygnować z jego usług. Uczestnik życia artystycznego nie musi też stawiać sobie żadnych celów. Właściwie może czuć się panem sytuacji. To od jego werdyktu wyrażanego poprzez zakup biletu na wystawę czy inną imprezę, kupno płyty lub książki, zależy los dzieła i artysty. W ramach demokratycznej wspólnoty estetycznej odbiorcy zajmują miejsce uprzywilejowane. Prowadzi to zaś do przejawiania specyficznych sposobów zachowań właściwych dla osób

${ }^{27} \mathrm{O}$ różnych koncepcjach autorytetu w sztuce pisałem w wyżej wspomnianej książce (ibidem) w rozdz. Autorytet w sztuce dawnej i nowoczesnej.

${ }^{28}$ Por. na ten temat D. Kuspit, Koniec sztuki, przeł. J. Borowski, Gdańsk 2004, s. 1-11. 
uprzywilejowanych. Dawniej jedną z ulubionych rozrywek zarezerwowanych dla klas wyższych było myślistwo. Zygmunt Bauman proponuje, żeby metaforę myśliwego przenieść do dzisiejszych czasów płynnej nowoczesności i uznać „myślistwo kulturowe” za „zajęcie pełnoetatowe”, występujące $\mathrm{w}$ różnych sytuacjach. Charakteryzując je, powołuje się Bauman na poglądy siedemnastowiecznego filozofa Blaise Pascala, który pisał, że polując nie dla zdobycia pożywienia, a dla rozrywki, szuka się jedynie zatrudnienia, które by odwróciło uwagę od myśli o sobie poprzez koncentrację na nieustannie czarującym i wabiącym celu. Metaforycznie zatem pojęte współczesne myślistwo kulturowe, jak pisze Bauman, „pochłania dużo uwagi i energii i pozostawia niewiele czasu na cokolwiek innego. Odwraca uwagę od nieskończoności zadania i odkłada ad calendas graecas moment refleksji, w trakcie której należałoby wprost stawić czoło niemożności ukończenia zadania”29. Jego zakończenie może okazać się jedynie osobistą porażką, dlatego lepiej wciąż „cieszyć się widokami i odgłosami z oddali” ${ }^{30}$. Uważam, że współcześni odbiorcy, uczestnicy wspólnoty estetycznej, czują się takimi myśliwymi. Krążą wśród różnorodnych propozycji artystycznych, reagując na te, które zdolne są choć na chwilę zwrócić ich uwagę. Nie przejmują się tym, że na decyzje ich wielki wpływ wywiera reklama i moda, że są sterowani z zewnątrz przez bodźce uwarunkowane kryteriami ekonomicznymi. Dawnych pośredników wpływających na charakter przeżyć estetycznych widzą dziś chętnie jako organizatorów łowów albo uczestników nagonki napędzającej zwierzynę do odstrzału. Dlatego nie chcą, żeby ingerowali w ich przyjemności, pragną tylko informacji o nowych, pojawiających się możliwościach wrażeń. Estetycy, którzy przez ostatnie wieki, jak pisał Welsch, reklamowali sztukę swymi teoriami, okazują się w nowej sytuacji mało przydatni. Ich reklama jest zbyt złożona i mało skuteczna. Dlatego poszukując nowego miejsca dla swej działalności, rezygnują z uprawiania „filozofii sztuki”, a zajmują się np. zagadnieniami estetyzacji życia codziennego, zooestetyką, estetyką polityki itp.

\footnotetext{
${ }^{29}$ Z. Bauman, Perpetuum mobile, [w:] idem, Między chwila a pięknem. O sztuce w rozpędzonym świecie, Łódź 2010, s. 31.

${ }^{30}$ Ibidem, s. 32.
} 


\section{Bibliografia}

Bauman Z., Między chwila a pięknem. O sztuce w rozpędzonym świecie, Łódź 2010.

Beardsley M. C., Aesthetics: Problems in Philosophy of Criticism, New York 1958.

Beardsley M. C., The Aesthetic Point of View. Selected Essays, eds. M. J. Wreen, M. D. Callen, Ithaca 1982.

Dziemidok B., Główne kontrowersje estetyki współczesnej, Warszawa 2002.

Eco U., Dzieło otwarte. Forma i nieokreśloność w poetykach współczesnych, przeł. J. Gałuszka, L. Eustachiewicz, A. Kreisberg, M. Olesiuk, Warszawa 1972.

Kuspit D., Koniec sztuki, przeł. J. Borowski, Gdańsk 2004.

Meyer U., Conceptual Art, New York 1972.

Popper F., Art - Action and Participation, London 1975.

Sztabiński G., Inne idee awangardy: wspólnota, wolność, autorytet, Warszawa 2011.

Tatarkiewicz W., Dzieje sześciu pojęć, Warszawa 1975.

Wallis M., Przeżycie i wartość, Kraków 1968.

Welsch W., Estetyka poza estetyką. O nowa postać estetyki, przeł. K. Guczalska, Kraków 2005.

Zmierzch estetyki - rzekomy czy autentyczny?, wybrał i wstępem opatrzył S. Morawski, t. II, Warszawa 1987. 